\title{
GREEN MARKETING: FACTORS INFLUENCE ON CONSUMER ATTITUDE AND PERCEPTION TOWARDS PURCHASING ECO FRIENDLY PRODUCTS.
}

\author{
Dr. Rambabu Lavuri ${ }^{1}$ \\ ${ }^{1}$ ICSSR-Post Doctoral Fellow, Dept. of Business Management, Osmania University \\ rambabu.lavuri@gmail.com \\ Prof. D. Sreeramulu ${ }^{2}$ \\ ${ }^{2}$ Dean Faculty of Management, Osmania University, Hyderabad, Telanagna, India. \\ profsreeramulu@gmail.com
}

\begin{abstract}
At present scenario, an environmental aspect has turned into a key issue. The green market concept has turn into the trendy expression in most recent decade because of sensational increment in environmental consciousness around the world. Purpose of the investigation is to find out the environmental consciousness and studying respondent's attitudes \& perception, and drive factors to purchasing towards green products. The research data were composed through survey and interview methods by the structure questionnaire from the 429 respondents from three districts of Telanagna state in India. The results revealed that media exposure had a significant impact on the consumer perception \& attitude, along these lines environmental driving factors show great influence on perception \& attitude towards purchasing eco friendly products and Consumers attitude and perception have positive impact on purchasing eco friendly products. As per results, respondents have positive association and more environmental consciousness by the purchasing of eco-friendly products. Finally, the study concluded that the consumers are familiar about the environmental aspects and also their green awareness is high. To increase the sales volume of ecological sustainable items, marketers need to adopt a better marketing mix for their eco-friendly items in order to change respondent's negative perception and develop eco-awareness towards green products. Similarly, government should take responsibility towards creating better awareness about environmental consciousness and eco friendly products by purchasing green products.
\end{abstract}

Keywords: Attitude \& perception, eco-friendly products, environmental consciousness, Green market, media exposure

\section{Introduction}

Biological situation and environmental security are the genuine threats that are being faced by society from the past few decades. Business enterprises and human life had a lot of impact because of the ecological issues. Green promoting paved a way in finding the reason behind ecological issues such as global warming, loss of bio-diversity, ozone exhaustion, contamination and deforestation. Recent survey results states that $88 \%$ of Americans believe that we have to take care of environment, but still $22 \%$ believe that it is the government which has to take care. From a report given in 2014, it is clear that $55 \%$ of buyers across 60 nations are interested in using the products from the organizations which are conscious about ecology even though the price of the product is higher. Indian outline expresses that $85 \%$ of the purchasers think about how green things are helpful for nature and $63 \%$ of the Indian buyers think about the green things. American Marketing Association (AMA) portray Green Marketing as "The progression of the things that are earth secure; Green exhibiting incorporates making and propelling the things and organizations that lands at the customer wants the extent that quality, cost and accessibility of the things. Progressively over they should not hurt the earth by any means (Polonsky, 1994,
Mishra \& sharma, 2010 and Rakshita, 2011). To the extent enormous business, Green issues and Environmental Issues are for the most stage used to delineate these that endeavor to confirm or displace the qualities of the situation with the assistance of organizing criticalness and additional benefits and reducing or discarding the use of risky bosses, sullying and squandering. It is moreover insinuated as an article that is basically pertinent to the world. Awareness among the consumers towards the ecological issues and green items is improving at a greater rate (R.Mahesh \& P.Gomathi 2016). Green promoting is the marketing of the items that are assumed to combine greater extent of environmental activities such as modification to manufacturing process, items and packaging to make them sustainable, as well as creating a new way of publicizing (faizan Zafar Sheikh, et al. 2014). In current era, ecological issues such as global warming, exhaustion of natural resources are affecting the decisions of consumers in purchasing a product directly or indirectly. The enthusiasm in humans and the desire to get the maximum with least effort resulted in destroying the fundamental supporting frameworks of life; i.e. air, water and land (Smitha 2009); the repost of world health organization stated that, Every year in India $5,27,700$ deaths are due to contamination of air and $21 \%$ of 
the transmittable diseases are getting spread because of Water pollution (Mannarswamy, 2011); In addition, Indians are least aware of the environmental issues among the 14 nationalities surveyed(National Geography, 2008). Climate has become a standard issue and buyers are getting progressively increasingly cognizant about their penchants and their effect on the earth (Krause, 1993). A research study concludes that $69 \%$ of the public accepts that their daily life is getting affected because of the contamination and environmental issues(Schlegemilch, 1996), which confirms the proposal that buyers are progressively picking or evading items depending on their climate effect (Ottman, 1992; McDougals, 1993, Coddington, 1993; Davis, 1993 and Grove et al, 1996. Along these lines, the impact on home grown issues is all the more truly conspicuous for each body right now and happens needing securing something in one structure or the other.

\section{RECENT RESEARCH REVIEWS}

\section{Media exposure}

Most researchers presumed that the media took on an amazing activity in the extensive dispersal of the environmental concern (Morrison and Lowe, 1984; Lowe and Rudig, 1987, Mitchell, 1990). In this manner, Raymond and Mazis (1997) battled for advertisers to utilize a media mix to give ideal conditions to an arranged purchaser interest gathering. For instance, TV ads might be utilized for showcasing the items, print commercials might be utilized to impart data that is progressively itemized and to build up a brand picture, and item bundling might be utilized to pull in shoppers at the purpose of offer (Belch and Belch 1995). Such media uses are typically combined into a single coordinated communication campaign. Schultz and Lauterborul (1993) portrayed media presentation as any open entrance for a reader, watcher, or crowd to see or hear a promotional message in a particular media vehicle. Presentation of media is a major driver of progress scattering and has a major impact on pioneers (Bass, 1969). Media introduction's most generally speaking effect on dispersing is that it spreads data of moves up to a huge assembling rapidly (Rogers 2003). Green and Peloza (2014) reviewed on effect of propelling offer type on earth neighbourly utilization and the evaluation translated that when respondents experience raised open commitment, otheradvantage offers are interminably persuasive; self-advantage demands work better in private settings. Rambabu $\mathbf{L}$ and Sreeramulu D (2019) study concluded that media exposure has a great impact on the consumer intention and knowledge towards green purchasing. Iman Khalid and Zainuddin (2011) examined expects to distinguish the impact of media presentation, on buy aim of without lead electronic items (green gadgets) among addresses, from USM designing grounds. The study found that media exposure had a significant positive influence on lectures purchase intention. Thus expanding the portion of media will improve purchaser awareness towards environmental issues, and subsequently, effect hopeful frames of mind as media assume a significant job in impacting the mentality of customers and their dedication perspectives in natural exercises and practices. In the view of previous research, media exposure had significant impact on the green consumers towards awareness and purchasing behaviour with concerned ecological issues.

\section{Attitude and perception}

The basic issue impacting the getting conduct of customers (Anu Varghese and Santhosh J. 2015) is nature of the thing, and the issue went facing, by the clients are nonattendance of transparency of things, critical cost and law progress. Incidentally, The impacts purchaser care and further drives them to buy green things are security, pay, regular concern, data, age , sexual direction, attitude, values, brand naming, packaging, etc. Showed up diversely in connection to buyer care in made nations Indian buyers are still less aware of the environmental issues (Manveer Kaur, et al. 2018); The consumers attitude will be treated as a Knowledge work, so that it will be formed by the manner in which people compose their convictions towards an organization and later structure their resulting buying conduct towards green items (Hawkins, et al. 2004); With a marketing strategy to advertise a "green" item (Tucker, et al. 2012), consumers with positive attitudes towards environmental protection react positively to both solid and feeble green item guarantees. Green new item presentations have a positive impact on the attitude of the brand; and the number of green messages, type of item and credibility of the source influence the image of the brand (Olsen et al. 2014). Rambabu L and Sreeramulu D (2019) studied that attitude and perception of consumers have a positive association with purchasing green products.

\section{Factors drive to purchasing}

When context variables such as personality traits were used, the predictive ability of the purchasing target of green items would be improved. The investigation brought up personality traits has a significant influence on the environmental behaviour. In this manner, personality traits would affect the purchasing intention of the green item (Gayathree D.A.G.P.K. 2016). The driving factors like ecological concern and products functional attributes are developed as two key determinants of consumers buying behaviour towards green items. It illustrates attitude and behaviour as the main predictors of consumers green buying behaviour (Yatish Joshi and Zillur Rahman, 2015). Consumers have the ability to prevent or decrease ecological damage by buying green items and by having positive attitude towards environmental protection (Grunert. 1995). Last few years, the number of people willing to buy green items has increased. Although, environmental concern and positive attitude of consumers regarding sustainability and green items, green market share stays restricted to just one to three percent of the entire industry (Jhons, bray and killburn, 2011). It prompts ecological variables to take on a minor job in customers who make decisions, and a large number of people ignore the common results of their purchases (Webb 
and Harris, Mohr, 2001). The frame of mind of the shopper, the emotional standard, the moral commitment, saw social control, the ace natural self-character and the preparation of the purchaser are the driving variables of the expectation to purchase green things. Buyers' mentality, saw social control, master ecological self personality and saw awareness of other's expectations have critical effect on the obtaining goal of Customers (Tan LP, Arli D, Yang L, Tjiptono F, 2018).

\section{OBJECTIVES AND HYPOTHESES OF THE STUDY}

The main fundamental destinations of the flow study of research.

- To analyse consumers demographics for inclined to purchase green products;

- To study Consumers perception and their attitude towards green purchasing;

- To identify major key factors that drive clients to green purchasing.

A research hypothesis is framed as shown in Figure 1. The figure shows the relationships between the independent variables (media exposure, Attitude and perception and factors which drive to purchasing), and dependent items (purchasing eco friendly products). In accordance with the research framework and the priori associations developed by studies, the following research hypotheses are developed and to be tested in current study.

- H1: Media exposures have positive influence on consumer's attitude and perception towards purchasing eco friendly products.

- H2: Key drive factors have positive impact on Consumers perception and attitudes towards Eco friendly purchasing.

- H3: Consumers attitude and perception have positive impact on purchasing eco friendly products.

\section{MATERIALS AND METHODS}

Research is a systematic enquiry approach, it explores poignant from the essential hypothesis to design of research and collection of the data (Myers, 1999). From this study, researchers have used this ways to confirm client's deliberate towards eco-friendly green products, and also this section involve the discussion on the data working for the study.

Participants and Procedure: The present research adopts analytical research design. For this research study, the essential data was collected from three districts of Telanagna state in India; those are Secunderabad, Hyderabad and Warangal, The scope the research study is limited to three districts of Telanagna state in India.

Tools and Data collections: Outlook on research objectives, a questionnaire for the respondents was drafted. A Structure and closed-ended questionnaire was prepared and distributed among the respondents for capturing their responses pertaining to variable of the Green products. The questionnaire was finalized after pre test. To ensure the relevance and suitability of research questionnaire, pre-test was conducted. The questionnaire was structure two parts; in the initial part has five demographic questions of respondents and the second part was made up four major factors with 22 questions distributed between four variables. Five questions were framed to know the influence of the media exposure on respondents; ten questions were included to assess the perception \& Knowledge Levels of the respondents towards Green items; and six questions analyse the degree of concerns for environmental protection. Each question measured different perception regarding the variable of eco-green products. Hence, respondents were given rate of responses about five eco green variables on the five point Likert scale, it has ranging from 5-Strongly agree to 1-Strongly Disagree. Composed research data were evaluated by using statistical tools like analysis of variance, Pearson correlation and multiple regressions has been used by using SPSS 23 windows version. Overall, 517 questionnaire were distributed to the sample respondents under the Convenience sampling method, we were able to receive feedback $82 \%$ (429)

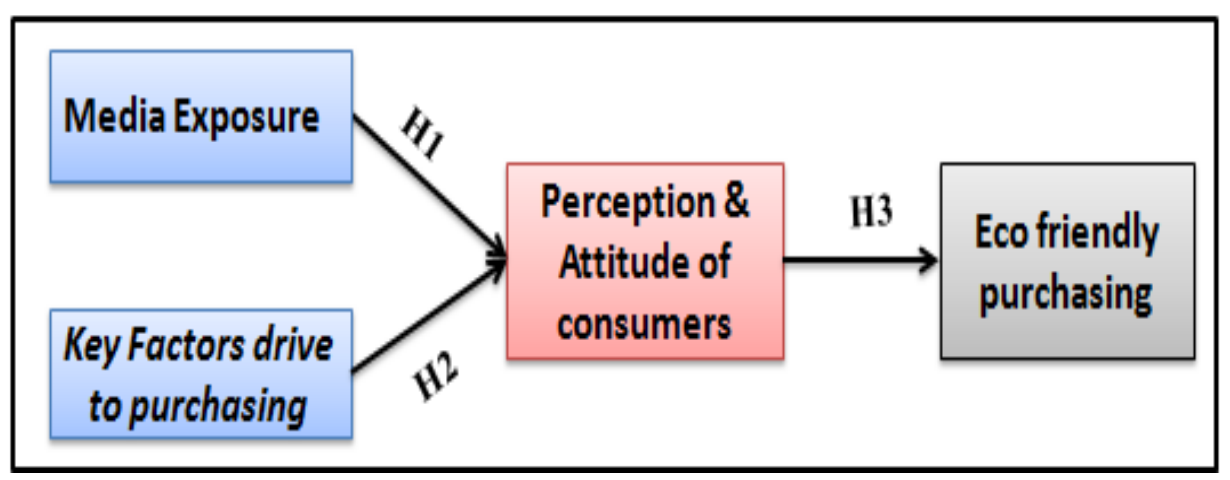

Figure 1: Hypothetical conceptual frame work 
of the respondents from the three districts of Telanagna state.

Respondents Demographic statistics: This section discloses the demographic statistics of clients; which includes respondent's age, gender, occupation, education and income status is presented in the table 3 .

\section{CONSEQUENCES AND DISCUSSIONS Reliability and Validity Measures}

To check scale reliability and validity in the current research study, researchers calculated the Cronbach's alpha coefficient for internal consistency of all variables and the cut-off score level is 0.70 ; by using SPSS packages. The analysis results were given in table 2 .

This confirms the validity and reliability of present study variables. Alpha values were calculated one after the other for each of the variables; to examine the scale validity and reliability of the destiny take a look at. The Cronbach's alpha values for Media exposure, Perception \& Attitude, Factor

Table 1: The Clients Demographic statistics

\begin{tabular}{|c|c|c|c|}
\hline \multirow{2}{*}{\multicolumn{2}{|c|}{ Clients demographics }} & \multicolumn{2}{|c|}{$(N=429)$} \\
\hline & & Frequency & $\%$ \\
\hline \multirow{4}{*}{ Age } & Below 25 years & 89 & 20.7 \\
\hline & $26-35$ years & 218 & 50.8 \\
\hline & $36-45$ years & 74 & 17.2 \\
\hline & 46 and Above & 48 & 11.2 \\
\hline \multirow{2}{*}{ Gender } & Male & 284 & 66.2 \\
\hline & Female & 145 & 33.8 \\
\hline \multirow{4}{*}{ Education } & Below Degree & 98 & 22.8 \\
\hline & Degree & 120 & 28.0 \\
\hline & PG & 139 & 32.4 \\
\hline & Above PG & 72 & 16.8 \\
\hline \multirow{4}{*}{ Occupation } & Govt employee & 131 & 30.5 \\
\hline & Private employee & 153 & 35.7 \\
\hline & Business & 51 & 11.9 \\
\hline & Other & 94 & 21.9 \\
\hline \multirow{4}{*}{$\begin{array}{l}\text { Monthly income } \\
\text { (in rupees) }\end{array}$} & Below 25,000 & 72 & 16.8 \\
\hline & $25,001-35,000$ & 187 & 43.6 \\
\hline & $35.001-45,000$ & 85 & 19.8 \\
\hline & 45,001 and Above & 85 & 19.8 \\
\hline
\end{tabular}

Table 2: Scale Construction

\begin{tabular}{|l|c|c|}
\hline \multicolumn{1}{|c|}{ Questionnaire } & Items & Alpha \\
\hline Media Exposure & Five & 0.761 \\
\hline Perception \& Attitude & Eight & 0.795 \\
\hline Factor drives to purchase & Five & 0.804 \\
\hline Eco friendly purchasing & four & 0.817 \\
\hline
\end{tabular}


Table 3: Research variables and sources

\begin{tabular}{|c|c|l|}
\hline S.No & \multicolumn{1}{|c|}{ Variables } & \multicolumn{1}{c|}{ Source } \\
\hline 1 & Media Exposure & $\begin{array}{l}\text { Iman Khalid A- Qader and Yuserrie Zainuddin (2011); } \\
\text { Rambabu L and Sreeramulu D (2019). }\end{array}$ \\
\hline 2 & Perception \& Attitude & $\begin{array}{l}\text { Sanjeev Kumar et al. (2012); Asha and Rathiha (2017); } \\
\text { Rambabu L and Sreeramulu D (2019). }\end{array}$ \\
\hline 3 & Factor drives to purchase & $\begin{array}{l}\text { Poornima Gayathree (2017); Rambabu L and Sreeramulu } \\
\text { D (2019). }\end{array}$ \\
\hline 4 & Eco friendly purchasing & $\begin{array}{l}\text { Asha and Rathiha (2017); Rambabu L and Sreeramulu D } \\
(2019) .\end{array}$ \\
\hline
\end{tabular}

Table 4: Descriptive Scale Statistics

\begin{tabular}{|c|c|c|c|c|}
\hline Variables & $\mathrm{N}$ & Mean & Std. Deviation & Variance \\
\hline Age in years & & & & 1.181 \\
\hline Gender & 429 & 2.58 & 0.461 & .213 \\
\hline Education & 429 & 1.31 & 1.062 & 1.128 \\
\hline Occupation & 429 & 3.36 & 1.163 & 1.353 \\
\hline Income in rupees & 429 & 2.89 & 1.138 & .494 \\
\hline Media Exposure & 429 & 2.91 & .60082 & .361 \\
\hline Perception \& Attitude & 429 & 3.8951 & .66977 & .461 \\
\hline Factor drives to purchase & 429 & 3.8042 & .67861 & \\
\hline Eco friendly purchasing & 429 & 3.6084 & & \\
\hline Valid N (list wise) & 429 & 3.6247 & & \\
\hline
\end{tabular}

drives to purchase and Eco friendly purchasing are observed to be $0.761,0.795,0.804$ and 0.817 . These values illustrated that research data have good and satisfactory validity and reliability score.

Table 4 reveals that the descriptive statistics of demographic profile. The major purpose to use descriptive statistics is to provide total summary of the collection of the data and also used for the measuring the central tendency and variability of the data. The disk indicate that the mean, Std. Deviation and Variance values of Demographic profiles of the respondents and green purchasing variables, mean statistics for Age, Gender, Education, Occupation and Monthly Income are found to be $2.58,1.31,3.36,2.89$, and 2.91; standard deviations of 
$1.181,0.461,1.062,1.163$ and 1.138. As well as above disk reveals that mean statistics for Media Exposure, Perception $\&$ Attitude, Factor drives to purchase and Eco friendly purchasing are found 3.8951, 3.8042, 3.6084 and 3.6247; Std. Deviation values are $.60082, .66977, .67861, .72973$; with the variance values are $.361,0.449,0.461$ and 0.533 respectively.

Table 5 explores that respondents recent green purchasing, $66 \%$ of respondents gave the response towards statement. $30 \%$ of respondents were purchase electronic applicants, $18 \%$ of respondents accounted for purchasing IT equipments. $16 \%$ of them were purchased Green packaging bags. Similarly, $13 \%, 12 \%$ and $8 \%$ of the respondents were purchased green food products, recyclable paper products and health and beauty items. The study also reveals that most of the respondents having positive awareness towards green items; but this awareness level not much influence on them towards purchasing green items.
Table 5 explores that respondents recent green purchasing, $66 \%$ of respondents gave the response towards statement. $30 \%$ of respondents were purchase electronic applicants, $18 \%$ of respondents accounted for purchasing IT equipments. $16 \%$ of them were purchased Green packaging bags. Similarly, $13 \%, 12 \%$ and $8 \%$ of the respondents were purchased green food products, recyclable paper products and health and beauty items. The study also reveals that most of the respondents having positive awareness towards green items; but this awareness level not much influence on them towards purchasing green items.

Table 6 revealed that awareness level of respondents. Six questions were asked to clients related to eco green items. The result found that $36 \%$ of the clients have good awareness about green items to be ecological friendly products, $23 \%$ of clients feel that green items were recyclable products. Similarly, $16 \%$ of them were aware as green items are more energy saver. However, $13 \%$ of them were believes that green items are Bio-

Table 5: 7 Recently Green items purchased by clients

\begin{tabular}{|c|c|c|c|}
\hline \multirow{2}{*}{ S.no } & \multirow{2}{*}{ Product Name } & \multicolumn{2}{|c|}{ (N=66\%; 283 out of 429) } \\
\cline { 3 - 4 } & & Frequency & \% \\
\hline 1 & Recyclable Paper products & 36 & 12.7 \\
\hline 2 & Food Products & 38 & 13.4 \\
\hline 4 & Health and Beauty products & 24 & 8.5 \\
\hline 5 & Electronic Applicants & 87 & 30.8 \\
\hline 6 & Green Packaging bags & 46 & 16.2 \\
\hline 7 & IT Equipments & 52 & 18.4 \\
\hline & Total response & $\mathbf{2 8 3}$ & $\mathbf{1 0 0 \%}$ \\
\hline
\end{tabular}

Table 6: Respondent's awareness about the green products

\begin{tabular}{|c|c|c|c|}
\hline \multirow{2}{*}{ S.no } & \multirow{2}{*}{ Statement } & \multicolumn{2}{|c|}{ (N=429) } \\
\cline { 3 - 4 } & & Frequency & \% \\
\hline 1 & Eco friendly & 157 & 36.6 \\
\hline 2 & Bio-degradable & 57 & 13.2 \\
\hline 3 & Recyclable & 99 & 23.1 \\
\hline 4 & Energy saver & 72 & 16.8 \\
\hline 5 & Healthy for occupants & 32 & 7.5 \\
\hline 6 & Non-Toxic products & 12 & 2.8 \\
\hline & Total & $\mathbf{4 2 9}$ & $\mathbf{1 0 0 \%}$ \\
\hline
\end{tabular}


degradable products. Finally, $7 \%$ and $2 \%$ of client's responses rate indicated that green items were Healthy for occupants and Non-Toxic products.

\section{Results of Analysis of variance}

(i) Analysis on positive influence of media exposure on client's intensions towards green purchasing.

- H1: Media exposures have positive influence on consumer's attitude and perception towards purchasing eco friendly products.

Table 7 reveals that media exposure and their $F$ values found to be statistically positive significant; meaning there by there is exposure of media have positive influence on consumer's attitude and perception towards purchasing eco friendly products. Media exposure $\mathrm{F}$ values in this situation are 11.869 , and the sig. value is $.000(p<0.05)$. Since the $F$ value is found to be significant.

(ii) Analysis on major factors that drive consumer's perception and attitudes towards purchasing Eco friendly product.
- H2: Key drive factors have positive impact on Consumers perception and attitudes towards purchasing Eco friendly product.

Table 8 reveals the ANOVA results, it shows that the 261.450 is the variance between groups and 593.543 is the variance within the groups and followed by the value of F-distribution is 46.692 and it significance value is .000 . Since the significance value is smaller than $\mathrm{p}$-value. The results concluded that key drive factor have positive impact on Consumers perception and attitudes towards Eco friendly purchasing.

(iii) Analysis on consumer's perception and attitudes towards Eco friendly purchasing.

- H3: Consumers attitude and perception have positive impact on purchasing eco friendly products.

Table 9 results shows that there is a mean difference among the groups; and the value of F-distribution is 32.131 and the sig. value is 0.00 , which is lesser distanced from the value 0.50 . Hence, results concluded that client's attitude and perception have positive impact on consumer's attitude and perception

Table 7: ANOVAs result

\begin{tabular}{|l|c|c|c|c|c|}
\hline & Sum of square & df & Mean square & F & Sig. \\
\hline Between Groups & 64.873 & 7 & 9.268 & 11.869 & \multirow{2}{*}{.000} \\
Within groups & 328.735 & 421 & .781 & & Supported \\
\hline total & 393.608 & 428 & & & \multirow{2}{*}{ Sun } \\
\hline
\end{tabular}

Table 8: ANOVAs result

\begin{tabular}{|l|c|c|c|c|c|}
\hline & Sum of square & Df & Mean square & F & Sig... \\
\hline Between groups & 261.450 & 4 & 65.363 & 46.692 & .000 \\
\hline Within Groups & 593.543 & 424 & 1.400 & & $(\mathrm{p}<0.05)$ \\
\hline total & 854.993 & 428 & & & Supported \\
\hline
\end{tabular}

Table 9: ANOVAs result

\begin{tabular}{|l|c|c|c|c|c|}
\hline & Sum of square & df & Mean square & $\mathrm{f}$ & Sig. \\
\hline Between groups & 199.012 & 4 & 49.753 & 32.131 & .000 \\
\hline Within Groups & 656.541 & 424 & 1.548 & & $(\mathrm{p}<0.05)$ \\
\hline Total & 855.552 & 428 & & & Supported \\
\hline
\end{tabular}


towards purchasing eco friendly products.

Table 10 discloses that Exposure variables like Friends/ Relatives as reference group $\left(\mathrm{r}=0.714^{* *}\right)$, News paper and Magazine $(\mathrm{r}=0.652 * *)$ are having strongly with positive correlation with the Consumer perception and attitudes regarding green products at the $1 \%$ significance level. Whereas, Internet Ads $\left(\mathrm{r}=-0.483^{* *}\right)$ and $\mathrm{TV}$ ads $\left(\mathrm{r}=0.569^{*}\right)$ having weak association with consumer intentions towards green products 5\% significance level, Internet Ads having negative correlation with the consumer perception and attitudes.

Desk 11 reveals that outcome of Pearson correlation analysis between driving factors and perception $\&$ attitudes of consumers. Key driving factors like Green products are recyclable and degradable $\left(\mathrm{r}=0.751^{* *}\right)$, Maintain Environmental and climate sustainability $\left(\mathrm{r}=0.722^{* *}\right)$ and
Awareness, perception levels on green products $\left(\mathrm{r}=0.701^{* *}\right)$ are having great positive association with perception and attitude of consumers at the $1 \%$ significance level. Followed by Influence of promotional ads of green products $(\mathrm{r}=$ $0.652 * *)$ and Green product having Better quality than non green products $\left(\mathrm{r}=-0.668^{* *}\right)$ having weak relationship with perception and attitude of consumers at the $5 \%$ significance level.

Table 12 indicates that results of Pearson correlation between consumers Perception $\&$ attitudes towards purchasing Eco friendly green product. Perception \& attitudes variables like Green products are Eco-friendly $(\mathrm{r}=0.759 * *)$, Green Products are having the high price $\left(\mathrm{r}=0.690^{* *}\right)$ and Green products are more Healthy and Safety $(\mathrm{r}=0.682 * *)$ are having strong and positive association with Green purchasing at the $1 \%$ significance level. Whereas, Green products are best

Table 10: Results of Correlations between the Media exposure and consumer's perception and attitudes

\begin{tabular}{|c|c|c|}
\hline S.no & Media exposure & Pearson Correlations (r) \\
\hline 1 & TV Ads & $.569^{*}$ \\
\hline 2 & News paper and Magazine & $.652^{* *}$ \\
\hline 3 & Outdoor Ads & $.599^{* *}$ \\
\hline 4 & Internet Ads & $-.483^{*}$ \\
\hline 5 & Friends/ Relatives & $.714^{* *}$ \\
\hline
\end{tabular}

Sig. level at $p<0.05$ at 2-tailed: *Sig. level at $p<0.01$ at 2-tailed: **

Table 11: Results of Correlations between key factors that drive Consumer perception \& attitudes

\begin{tabular}{|c|l|c|}
\hline S.No & \multicolumn{1}{|c|}{ Driving factors towards purchasing } & Pearson Correlations $(r)$ \\
\hline 1 & Awareness, perception levels on green products & $.701^{* *}$ \\
\hline 2 & Green product having Better quality than non green products & $.668^{* *}$ \\
\hline 3 & Influence of promotional ads of green products & $.652^{* *}$ \\
\hline 4 & Maintain Environmental and climate sustainability & $.722^{* *}$ \\
\hline 5 & Green products are recyclable and degradable & $.751^{* *}$ \\
\hline 6 & Protecting an environment to ensure healthy living & $.696^{* *}$ \\
\hline
\end{tabular}

*. Sig. level at $p<0.05(2$-tailed); **. Sig. level at $p<0.001(2$-tailed) 
Table 12: Results of Correlations between Perception \& attitudes and purchasing Eco friendly

\begin{tabular}{|c|l|c|}
\hline S.No & \multicolumn{1}{|c|}{ Perception and attitudes } & Pearson Correlations (r) \\
\hline 1 & Green Product that uses less Agro-chemicals & $.631^{*}$ \\
\hline 2 & Green products are having eco-packing & $.664^{*}$ \\
\hline 3 & Green products are Eco-friendly & $.759^{* *}$ \\
\hline 4 & Green Products are having the high price & $.690^{* *}$ \\
\hline 5 & Green products having High Quality & $.655^{*}$ \\
\hline 6 & Green products are more Healthy and Safety & $.682^{* *}$ \\
\hline 7 & Green products having High performance level & $.638^{* *}$ \\
\hline 8 & Green products are best Labelling & $.573^{* *}$ \\
\hline
\end{tabular}

Labelling $\left(\mathrm{r}=-0.573^{* *}\right)$, Green Product that uses less Agrochemicals $\left(\mathrm{r}=-0.631^{*}\right)$ and Green products having High performance level $\left(\mathrm{r}=-0.638^{*}\right)$ having weak relationship with green purchasing at the $1 \%$ and $5 \%$ significance level.

Results of Multiple Regressions: It is a statistical apparatus used to obtain the value estimation of a model from predictors; it clarifies the association among predictors and dependent factors. Below a table demonstrates that the development of the speculation of the hypothesis framework.

Table 13 disclose that summary results of Multiple Regressions, total three models developed to evaluate the association among the independent items and dependent items in the research study. The table revealed that, all the regression models F-values are statistically significant. The Model-1 illustrates that exposure of media had a significant impact on consumers perception \& Attitude towards purchasing Eco friendly product $(\beta=0.119, \mathrm{p} \leq 0.001)$, with $27.1 \%$ of variance explained by the independent predictors. Hence, hypothesis Hal is strictly supported. From the model-2, major key factors of green items; which was considered in this research study, have positive impact on consumers perception
$\&$ Attitude $(\beta=0.276, \mathrm{p} \leq 0.001)$ with $51.1 \%$ variance caused by the predictors. Similarly, model-3, consumer have great attitude $\&$ perception regarding green products $(\beta=0.302, \mathrm{p} \leq$ 0.001 ) which explain $48.3 \%$ of variance caused by predictors. So, it indicates that Ha3 hypothesis is supported.

\section{RESEARCH IMPLICATIONS AND LIMITATIONS}

In India, environmental issues are rising quickly. Practicing ecological awareness has turned into the new victory mantra and is being examined by people from every one of the life. As per the research finding, researchers considered four major factors with 22 questions which mostly influence the respondent's buying behaviour for the green items in three districts of Telanagna. Present research partying that respondents has ecological consciousness and concerned about environmental protection; most of respondents are buying eco-friendly items and to support ecological protection. The study extracted major key factors that respondents consider for green purchasing; those are Media exposure, Environmental Factors drives to purchase, perception \& attitude, and eco friendly green purchasing. Research illuminates regarding key indicators of respondents deliberates towards eco-green purchasing. Along these lines, it will help policy makers

Table 13: Summary results of Multiple Regressions

\begin{tabular}{|c|c|c|c|c|c|c|}
\hline Model & $I V$ & $D P$ & $R^{2}$ & $\beta$ & F-value & Sig. \\
\hline 1 & Media Exposure & Perception \& Attitude & .271 & .119 & 24.301 & .000 \\
\hline 2 & Factor drives to purchase & Perception \& Attitude & .511 & .276 & 37.638 & .000 \\
\hline 3 & Perception \& Attitude & Purchasing Eco- friendly products & .483 & .302 & 29.095 & .000 \\
\hline
\end{tabular}

Note: IV: Independent variable; DP: Dependent Variable 
and managers in formulating and executing strategies to promote green purchasing. The study results concluded that consumer's had great consciousness towards environmental protection and issues. Media exposure had a significant impact on the consumer perception $\&$ attitude, along these lines environmental driving factors show great influence on perception \& attitude towards purchasing eco friendly products and Consumers attitude and perception have positive impact on purchasing eco friendly products.

Green companies need to provide better information regarding green items through media ads. They should focus on different types of media ads for creating more awareness towards eco-friendly green items. Green progressing is a best strategy to assume and accomplish the objectives with ecofriendly activities. Hence, the government should find a way to produce the items that don't damage environment and avoid toxic chemicals; and steady moves ought to be made by govt, instructive social orders, NGOs, business organizations and society to raise awareness among the purchasers to support eco-accommodating green buying.

Research implications: The Central message of research directed to dismember the desire for customers Green Consumerism, to look at the factors that influence customers purchase point of green stock, The results counsel that consumer from the picked space having amazing getting mode and sought after with they're having wonderful biological included, in any case they're not pay high an impetus towards green commercialization. Finally, the present examination paper exhibited that respondent's desires having a direct association towards purchase of green items. From this green promoting progressing, having wonderful position towards the long continued running by that have reasonable involvement in additional green customers. This paper reveals that buyers wish eco-pleasing new stock from the creates, all things considered, it serves to sponsors to showcase and extend care for youth and new customers towards green stock by pondering environmental and quality points of view to draw on them. This paper encourages to academician to know the supporter goal, data and awareness level and drive that are influential on the buy of green products. It encourages them to grow new unique models towards customer conduct at the reason for buying.

Limitation of study: The research geographical area is limited to five selected cities from three states of India only. Thus, the research result and conclusions have its own boundaries. The researchers used convenience approach for the knowledge assortment that makes the study consequences not promptly generalizable. Rural market was not considered in this research, there is a scope for investigating green marketing position in rural area.

\section{References}

1. Bass, F. M., 1969. A New Product Growth Model for Consumer Durables.. Management Science, pp. 215-227.
2. Blech, G. \& Blech, M.A., n.d. Advertising and Promotions: an Integrated Marketing Communications Perspective., New York: s.n.

3. Bray, J., Johns, N., \& Kilburn, D, 2011. An exploratory study into the factors impeding ethical consumption.. Journal of Business Ethics, pp. 597-608.

4. Coddington, W., 1993. Environmental Marketing: Positive Strategies for Reaching the Green Consumer.. New York,United States: McGraw-Hill Inc..

5. D.A.G.P.K, G., 2016. Factors Affecting the Purchasing Intention of Green Products. Sri Lanka Journal of Marketing, Jan- June, vol-2(No 1).

6. D, A., Tan LP, Tjiptono F \& Yng L, 2018. Exploring consumers purchase intention towards green products in an emerging market: The role of consumers perceived readiness, s.1.: Int J Consum Stud..

7. Davis, J., 1993. Strategies for Environmental Advertising.. Journal of Consumer Marketing, pp. 23-25.

8. DeFleur, M. \& Everette Dennis, 1998. Understanding Mass Media. 6th ed. s.1.:Boston.

9. Dheivanai, A. a., 2017. An Analytical Study on Consumers Awareness Towards Green Fast Moving Consumer Goods In Coimbatore District. International Journal of Mnagement Studies, Vol-IV(Issue-4).

10. Faizan Zafar Sheikh, 2014. Consumer Green behaviour toward Green Products and Green Purchase Decision. International Journal of Multidisciplinarry Sciences and Engineering, Volume Vol. 5, pp. 1-9.

11. Gayathree, P., 2017. Factors Affecting the Purchasing Intention of Green Products.. Sri Lanka Journal of Marketing, Vol 2(No 1).

12. Grove, S. J., Fisk, R.P.,, Pickett, G. M \& Kangun, N., 1996. Going Green in the Service Sector Social Responsibility Issues, Implications and Implementation. European Journal of Marketing, Volume 30, pp. 56-66.

13. Grunert, S. C. \& Juhl, H. J., 1995. Vlaues, environmental attitudes, and buying of organic foods. Journal of economic psychology, Issue 16(1), pp. 39-62.

14. Hawkins, D. I., Best, R. J., \& Concey, K. A., , 2004. Consumer Behaviour: Building Market Strategy. 9th ed. Irwin: McGraw-Hill.

15. Joshi, Y. \& Zillur Rahman, 2015. Factors Affecting Green Purchase Behaviour and Future Research Directions, s.l.: International Strategic Management Review.

16. Joshi, Y. \& Zillur Rahman, 2015. Factors Affecting Green Purchase Behaviour and Future Research Directions.. International Strategic Management Review, Volume 3, pp. 128-143.

17. Kaur, M. \& Dr. Ambika Bhatia, 2018. The impact of Consumer Awarenss on buying behaviour of green products.. International Journal of Scientific Research and Management, Volume 06(Issue 04), pp. 250-255.

18. Khalid, I. \& Zainuddin, 2011. The Impact of Media Exposure on Intension to Purchase Green Electronic Products amongest Lecturers. International Journal of Business and Management, Vol.6(No.3).

19. Krause, D., 1993. Environmental Conciousness: An Empirical Study. Journal of Environment and Behavior, pp. 126-42.

20. Lowe, P. \& D. Morrison, 1984. Bad news or good news: Environmental politics and mass media.. Sociological Review, Volume Vol.32, pp. 75-90.

21. Lowe, P. \& W. Rudig, 1987. Review article: Political ecology and the social science- The state of art.. British Journal of Political Science, Volume vol.16, pp. 513-550.

22. Mahesh, R. \& P. Gomathi, 2016. A Study on Rural Consumers Buying Behaviour of Green Products with Reference to Selected Villages in Tiruppur District.. International Journal of Engineering and Management Research, volume-6(Issue-1), pp. 15-20.

23. Mannarswamy, S., 2011. A Study of Environmental Awareness and the Changing Attitude of the students and the Public in Coimbatore towards Green Products.. Research Journal of Social Science and Management, pp. $75-84$. 
24. Mannarswamy, S., 2011. A Study of Environmental Awareness and the Changing Attitude of the Students and the Public in Coimbatore towards Green Products.. Research Journal of Social Science and Management, Volume 1, pp. 75-84.

25. Mazis \& Raymond, 1997. Consumer perceptions of health claims in advertisements and on food labels.. The Journal of consumer affairs(USA), Vol:31(Issue:1).

26. McDougall, G. H. G., 1993. The Green Movement in Canada: Implications for Marketing Strategy.. Journal of International Consumer Marketing, Issue 5, pp. 69-87.

27. Mishra, P. \& Sharma, P., 2010. Green Marketing in India: Emerging Opportunities and Challenges.. Journal of Engineering, Science and Management Education, Volume 3, pp. 9-14.

28. Mitchell, R., 1990. "Public opinion and the green lobby: Poised for the 1990s?", s.1.: s.n.

29. Oslen, M. C., Slotegraaf \& Chandukala, S. R., 2014. Green claims and message frames: How green new products change brand attitude. Journal of Marketing, Volume 78, pp. 119-137.

30. Ottman, J., 2008. The five simple rules of green marketing.. Design Management Review, Vol.19(4), pp. 65-69.

31. Polonsky, M. J., 1994. An Introduction to Green Marketing.. Electronic Green Jounal, Volume 1, pp. 1-9.

32. R., M. \& sakthivel, 2015. Customer's attitude and awareness towards green products with reference to Coimbatore- An analytical study.. International Journal of Multidisciplinary Research and Development, 2(1), pp. 152-158.

33. Rakshitha, T., 2011. Green Marketing. Indian Streams Research Journal, Volume 1, pp. 1-10.
34. Rambabu L and Sreeramulu D. (2019). Green products and consumer awareness level: A study. EPRA-International Journal of Multidisciplinary Research, Vol.5 (6), 88-93.

35. Rambabu L and Sreeramulu D (2019). Fmcg Green Marketing: A Study on Pre-Consumption Perspective of Customers. International Journal of Innovative Research in Management Studies, Vol. 4 (6); 1-11.

36. Schlegemilch, B., Bohlen, G.M., \& Diamantopoulos,A., 1996. The Link between Green Purchasing Decisions and Measures of Environment Consciousness.. European Journal of Marketing, Volume 30, pp. 35-55.

37. Schultz, P. \& Lauterborul, Z.C., 1993. Values and pro environmental behaviour: A five -country survey.. Journal of Cross-Cultral Psychology, 29(4), pp. 540-558.

38. Smith, A., 2009. The Wealth of Nation- A Landmark Classic by Adam Smith. Thriffy Books.

39. Tolliver-Nigro, H., 2009. "Green Market to Grow 267 Percent by 2015,", s.l.: Matter Network

40. Tucker, E., Rifon, N.J.,, Lee,E. M., \& Reece, B.B., 2012. Consumer receptivity to green ads: A test of green claim types and the role of individual consumer characteristics for green ad response.. Journal of Advertising, Volume 41, pp. 9-23.

41. Varghese, A. \& Santhosh, J., n.d. A Study on consumers perception on eco-friendly product with reference to Kollam district in Kerala.. EPRA International Journal of economic and business review.

42. Vig, N. \& M.E. Kraft(eds), n.d. In Environmental Policy in the 1990s: Towards a new agenda.. Congressional Quarterly, pp. 81-99.

43. Yatish Joshi \& Zillur Rhman., 2015. Factors affecting green purchase behaviour and future research Directions. International strategic management review, pp.128-143. 